\title{
Ultrasensitive electrochemical genosensor for direct detection of specific RNA sequences derived from avian influenza viruses present in biological samples*
}

\author{
Kamila Malecka1 ${ }^{1}$ Edyta Świętoń2, Peter Verwilst ${ }^{3}$, Anna Stachyra4, Agnieszka Sirko4, \\ Wim Dehaen ${ }^{5}$, Jerzy Radecki ${ }^{1}$ and Hanna Radecka1⿴
}

IInstitute of Animal Reproduction and Food Research, Polish Academy of Sciences, Olsztyn, Poland; ${ }^{2}$ National Veterinary Research Institute, Puławy, Poland; ${ }^{3}$ Korea University, Department of Chemistry, Seoul, South Korea; ${ }^{4}$ Institute of Biochemistry and Biophysics, Polish Academy of

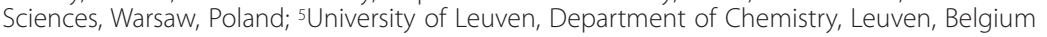

\begin{abstract}
An electrochemical genosensor based on an epoxyphenanthroline-Fe(III)- $\mathrm{NH}_{2}$-ssDNA layer for the detection of RNA derived from Avian Influenza is presented. The biosensor preparation consists of: (I) modification of gold electrodes with aminoethanethiol, (II) modification of the self-assembled monolayer of aminoethanethiol with 5,6-epoxy-5,6-dihydro-[1,10]-phenanthroline using "click" chemistry, (III) a first step of complexation of $\mathrm{Fe}$ (III) by 5,6-epoxy-5,6-dihydro-[1,10]-phenanthroline, (IV) a second step of complexation of $\mathrm{Fe}$ (III) by 5,6-epoxy-5,6-dihydro-[1,10]-phenanthroline, (V) immobilization of the single stranded amino-DNA probe via "click" chemistry between epoxy and amino groups. The interactions between the ssDNA probe and RNA targets were explored with Osteryoung Square Wave Voltammetry. The genosensor showed a remarkable detection limit of 3 copies/ $\mu \mathrm{L}$ ( $5 \mathrm{aM}$ ) for RNA extracted from A/swan/ Poland/305/06 (H5N1) containing a fully complementary sequence. A linear dynamic range for this sequence was observed from $3.0 \times 10^{3}$ to $3.0 \times 10^{5}$ [copies/ $\mu \mathrm{l}$ ]. RNA extracted from A/mallard/Poland/446/09 (H7N7), containing a non-complementary sequence, generated a much weaker response. Moreover, the developed genosensor allows to distinguish RNA present in biological samples having 2, 3 and 4 mismatches. This biosensing approach can become a potential alternative tool for detecting RNA samples in biomedical research and early clinical diagnosis of avian influenza viruses.
\end{abstract}

Key words: RNA biological samples, redox-active layer, electrochemical genosensor, square wave voltammetry, mismatched base pairs

Received: 30 January, 2019; revised: 2 July, 2019; accepted: 06 July, 2019; available on-line: 22 August, 2019

⿶e-mail: h.radecka@pan.olsztyn.pl

*Acknowledgements of Financial Support: This work was funded by the National Centre for Research and Development (NCBiR) under grant no. PBS2/A7/14/2014, grant no. 679/N-BELGIA/2010/0, COST Action CM10005 "Supramolecular Chemistry in Water" and Institute of Animal Reproduction and Food Research, Polish Academy of Sciences, Olsztyn, Poland.

Abbreviations: AuE, gold electrode; AET, 2-aminoethanethiol hydrochloride; AN, acetonitrile; PBS, phosphate buffer saline; EpoxyPhen, 5,6-epoxy-5,6-dihydro-[1,10]-phenanthroline; $\mathrm{NH}_{2}$-ssDNA, amino-terminated single stranded DNA probe; OSWV, Osteryoung Square Wave Voltammetry

\section{INTRODUCTION}

Avian influenza (AI) is a contagious disease caused by highly pathogenic (HP) viruses, especially type A viruses
H5 and H7. Globally, HP-AIVs cause huge economic losses and serious risks to human health. Hundreds of millions of domestic fowl died as a result of infection and slaughter to control the escalation of the epidemic (Śmietanka et al., 2017). In addition, the virus poses a risk of transferring to humans. It is extremely important to provide a device capable of detecting potential outbreaks of avian influenza viruses in an easy, fast and specific way (Fisher et al., 2007; Śmietanka \& Minta, 2014; Li et al., 2017).

The development of DNA biosensors has become a field of great interest and is used in various areas such as medical diagnostics, environmental control, food industry, forensics and pharmacy (Bahadır \& Sezgintürk, 2015; Mukama et al., 2017). Genosensors are based on a highly biospecific interaction between single-stranded DNA (ssDNA, DNA probe) immobilized on a solid substrate surface and complementary DNA or RNA sequence present in the sample solution. Especially electrochemical genosensors are very promising as devices suitable for point-of-care diagnostics or multiplexed platforms for rapid, simple and inexpensive research of nucleic acids (NA) (Shojaei et al., 2014; Radecka \& Radecki 2015, 2016; Mehrotra, 2016; Abi et al., 2018). Although significant progress has been made in the past few years, the performance of genosensors in biological samples has been appraised in only a small part of the published research papers (Paniel et al., 2013; Manzanares-Palenzuela et al., 2017; Ozkan-Ariksoysal et al., 2017).

Various types of DNA biosensors for detecting avian influenza viruses are widely discussed in the scientific literature. Recent review papers show a wide variety in the development of genosensors, from the simplest to the most complex multi-step procedures ( $\mathrm{Li}$ et al., 2017; Tosar et al., 2017; Abi et al., 2018).

In recent years, our laboratory has developed several DNA biosensors for AIV detection, which are very promising for diagnostic purposes. These tools were capable of detecting not only short sequences of ssDNA, but also double-stranded PCR products (ca. $180 \mathrm{bp}$ ) and RNA transcripts (ca. $280 \mathrm{nt}$ ) containing regions complementary to the probe (Malecka et al., 2012, Malecka et al., 2013, Malecka et al., 2015, Malecka et al., 2016; Grabowska et al., 2013, Grabowska et al., 2014a, Grabowska et al., 2014b; Kurzątkowska et al., 2015; Kaur et al., 2018).

This work demonstrates the electrochemical detection of RNA extracted from influenza viruses and the verification of the genosensor selectivity using viral RNAs with a different number of mismatched base pairs in the 
Table 1. Strains of avian influenza viruses, which were used for hybridization processes.

Total RNA was extracted from the indicated virus strains. The probe was $100 \%$ complementary to the RNA segment encoding the C-terminal part of HA1 hemagglutinin (HA) domain of the RNA1 sample, which was isolated from the A/swan/Poland/305/06 (H5N1). The mismatches of the probe to the other RNA samples are bolded and underlined. The accession numbers of the nucleotide sequences of the respective $\mathrm{HA}$ regions are provided.

\begin{tabular}{|c|c|c|}
\hline Sample & $\begin{array}{l}\text { Name of the virus } \\
\text { Sequence complementary to the probe }\left(3^{\prime}-5^{\prime}\right)\end{array}$ & $\begin{array}{l}\text { Accession number of the HA } \\
\text { nucleotide sequence (GISAID Database) }\end{array}$ \\
\hline RNA1 & $\begin{array}{l}\text { A/swan/Poland/305/06 (H5N1) } \\
\text { GGAGUUCCUCUCUCUUCUUC }\end{array}$ & EPI156789 \\
\hline RNA2 & $\begin{array}{l}\text { A/turkey/Poland/R3249/07 (H5N1) } \\
\text { GGAGUCCCCCUUUCUUCUUC }\end{array}$ & EPI171604 \\
\hline RNA3 & $\begin{array}{l}\text { A/graylag goose/Poland/74/10 (H5N2) } \\
\text { GGAGUU ÚCUCUCU GuUCU드 }\end{array}$ & EPI837534 \\
\hline RNA4 & $\begin{array}{l}\text { A/mallard/Poland/175/11 (H5N3) } \\
\text { GGGGUUUCUCUCU GUUCU드 }\end{array}$ & EPI837712 \\
\hline RNA5 & $\begin{array}{l}\mathrm{A} / \text { mallard/Poland/446/09 }(\mathrm{H} 7 \mathrm{~N} 7) \\
\text { negative reference }\end{array}$ & EPI254381 \\
\hline
\end{tabular}

region complementary to the probe. The electrochemical genosensor was developed based on the epoxy-phenanthroline-Fe(III) electroactive layer (Malecka et al., 2015).

\section{MATERIALS AND METHODS}

Reagents and biomaterials. 2-aminoethanethiol hydrochloride (AET), acetonitrile (AN), iron chloride (III), and phosphate buffer saline (PBS) components $(10 \mathrm{mM}$ $\mathrm{KH}_{2} \mathrm{PO}_{4}, 1.8 \mathrm{mM} \mathrm{Na}_{2} \mathrm{HPO}_{4}, 137 \mathrm{mM} \mathrm{NaCl}$ and $2.7 \mathrm{mM}$ $\mathrm{KCl})$ were supplied by Sigma-Aldrich. Alumina slurries $(0.3$ and $0.05 \mu \mathrm{m})$ were obtained from Buehler (USA). Ethanol (EtOH), hydrogen peroxide (HP), methanol $(\mathrm{MeOH})$, potassium hydroxide and sulfuric acid were purchased from POCh (Poland). 5,6-Epoxy-5,6-dihydro$[1,10]$-phenanthroline (Epoxy-Phen) was synthesized by the group of Prof. Wim Dehaen from University of Leuven (Belgium). The modified oligonucleotide $\mathrm{NH}_{2}$-ssDNA (5'- $\mathrm{NH}_{2}-\left(\mathrm{CH}_{2}\right)_{6}$-CCT CAA GGA GAG AGA AGA AG-3'), which was used as a probe to be attached to a surface of a gold electrode, was synthesized by Biomers (Germany).

The RNA samples were obtained from the Department of Poultry Diseases of National Veterinary Research Institute in Puławy (Poland). The influenza viruses were grown in the infected chicken embryos. RNA was extracted from viral particles present in allantoic fluid using the commercial Syngen Viral Mini Kit.

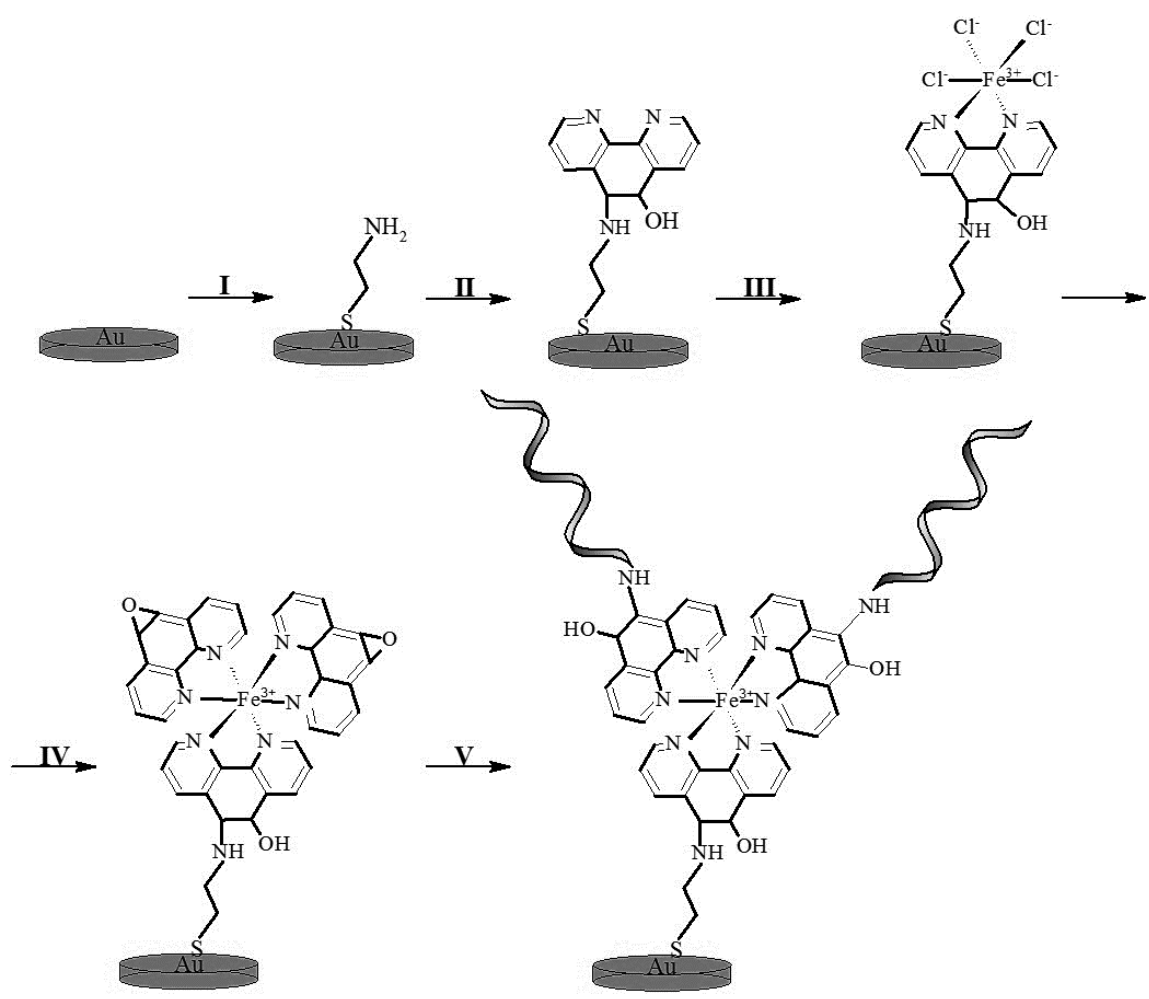

Scheme 1. Schematic representation of the genosensor preparation. 
Table 2. Values of the $\Delta \mathrm{I}=\mathrm{I}_{\mathrm{n}}-\mathrm{I}_{0}[\mu \mathrm{A}]$ and standard deviations (S.D.) for a given concentration of tested RNA samples $\left(I_{n}\right.$ is the value of the peak current measured in the presence of the RNA target and $I_{0}$ is the value of the peak current in pure PBS (before applying the analyte)).

\begin{tabular}{llll}
\hline Sample & $\mathrm{C}[$ copies $/ \mu \mathrm{L}]$ & $\Delta \mathrm{l}=\mathrm{I}_{\mathrm{n}} \mathrm{I}_{0}[\mu \mathrm{A}]$ & S.D. \\
\hline & 3000 & -0.054 & 0.006 \\
RNA1 & 30000 & -0.096 & 0.005 \\
& 300000 & -0.137 & 0.006 \\
& 100 & -0.032 & 0.007 \\
RNA2 & 1000 & -0.071 & 0.003 \\
& 10000 & -0.100 & 0.004 \\
& 1000 & -0.025 & 0.004 \\
RNA3 & 10000 & -0.052 & 0.006 \\
& 100000 & -0.089 & 0.003 \\
& 400 & -0.019 & 0.002 \\
& 4000 & -0.047 & 0.001 \\
RNA4 & 40000 & -0.080 & 0.002 \\
& 500 & -0.012 & 0.002 \\
\hdashline & 5000 & -0.034 & 0.005 \\
& 50000 & -0.061 & 0.004 \\
\hline
\end{tabular}

The following RNA samples were analyzed: RNA1 - containing a region with full complementarity to the $\mathrm{NH}_{2}-\mathrm{NC} 3$ DNA probe; RNA2, RNA3 and RNA4 - containing two, three and four mismatches in that region, respectively, RNA5 - the control RNA from different virus subtype used as a negative reference (Table 1).

The total RNA concentration in the sample was determined spectrophotometrically by measuring the absorbance at a wavelength of $260 \mathrm{~nm}$ on a Nanodrop spectrophotometer (Thermoscientific, USA).

The attachment of the $\mathrm{NH}_{2}$-ssDNA probe was carried out in acetonitrile solution (AN). The hybridization processes were carried out in PBS $\mathrm{pH} 7.4$ containing $10 \mathrm{mM} \mathrm{KH}_{2} \mathrm{PO}_{4}, 1.8 \mathrm{mM} \mathrm{Na} \mathrm{HPO}_{4}, 137 \mathrm{mM} \mathrm{NaCl}$ and $2.7 \mathrm{mM} \mathrm{KCl}$, prepared with sterile, nuclease free water supplied by Sigma-Aldrich. All aqueous solutions used for the pretreatment of the gold electrodes were prepared using autoclaved Milli-Q water, with a resistivity of $18.2 \mathrm{M} \Omega \cdot \mathrm{cm}^{-1}$ (Millipore Corporation, USA). Reagents and solvents were of analytical grade and used without further purification. All experiments were carried out at room temperature (rt).

Preparation of the genosensor. The detailed description of the genosensor preparation is included in our previous article (Malecka et al., 2015). Briefly, it consists of the following steps: (I) modification of gold electrode surface with AET; (II) attachment of EpoxyPhen to self-assembled AET monolayer using "click" chemistry; (III) the first step of complexation of Fe(III) by Epoxy-Phen; (IV) the second step of complexation of $\mathrm{Fe}(\mathrm{III})$ by Epoxy-Phen; (V) immobilization of single stranded $\mathrm{NH}_{2}$-DNA probe $\left(5^{\prime}-\mathrm{NH}_{2}-\left(\mathrm{CH}_{2}\right)_{6}-\right.$ CCTCAAGGAGAGAGAAGAAG-3") via "click" chemistry reaction (Scheme 1).

Hybridization processes. The RNA targets were diluted in the PBS hybridization buffer ( $\mathrm{pH} 7.4)$ according to Table 2.
$10 \mu \mathrm{L}$ of variable concentrations of RNA target solutions in PBS pH 7.4 were dropped on the surface of gold electrode modified with AuE/AET/Fe(III)(EpoxyPhen) $)_{3} / \mathrm{NH}_{2}$-ssDNA redox-active layer for 30 minutes at room temperature. Then, the electrodes were flushed with $5 \mathrm{~mL}$ of PBS, pH 7.4 in order to remove the unbound targets.

The hybridization processes were controlled using Osteryoung Square Wave Voltammetry (OSWV).

Electrochemical measurements. All electrochemical measurements were carried out with the AutoLab potentiostat-galvanostat (Eco Chemie, Utrecht, Netherlands) with a three-electrode configuration. Potentials were measured versus the $\mathrm{Ag} / \mathrm{AgCl}$ (saturated $3 \mathrm{M} \mathrm{KCl}$ ) electrode, and a platinum wire was used as the auxiliary electrode. Voltammetric measurements were performed in an electrochemical cell of $5 \mathrm{~mL}$ volume. In the OSWV technique, a potential window from $+0.4 \mathrm{~V}$ to $-0.15 \mathrm{~V}$, a step potential of $0.001 \mathrm{~V}$, square-wave frequency of 25 $\mathrm{Hz}$ and amplitude of $0.05 \mathrm{~V}$ were applied.

All measurements were carried out in PBS buffer deaerated with nitrogen for 15 min. During all measurements, a gentle nitrogen flow over the sample solution was also used.

Electrode responses are expressed as: $\Delta I=\left(I_{n}-I_{0}\right)[\mu A]$, where $I_{n}$ is the peak current value measured in the presence of the RNA target and $I_{0}$ the peak current value in pure PBS (before applying the analyte).

\section{RESULTS AND DISCUSSION}

\section{Preparation of the genosensor - successive steps of electrode modification}

The successive steps of the genosensor preparation are shown in Scheme 1. A detailed description of the preparation of this biosensor based on the AuE/AET/ $\mathrm{Fe}(\mathrm{III})$ (Epoxy-Phen) ${ }_{3} / \mathrm{NH}_{2}$-ssDNA redox-active layer is presented in our previous paper (Malecka et al., 2015). However, in contrast to the previous work, here the genosensor was used to analyze RNA extracted directly from the biological material, which were influenza viruses amplified in chicken embryos. RNA was extracted from four avian influenza viruses (Table 1). Not only complementary (RNA1) and non-complementary (RNA5) sequences were tested, but also RNA with 2, 3 or 4 mismatches within the target region.

\section{Detection of complementary RNA in biological samples}

The genosensor selectivity and sensitivity were determined using five RNA samples, with full (RNA1), partial (RNA2, RNA3, RNA4) or without (RNA5) complementarity to the 20 -mer $\mathrm{NH}_{2}$-ssDNA probe. Representative OSW voltammograms recorded in the presence of RNA1 and RNA5 are shown in Fig. $1 \mathrm{~A}$ and $1 \mathrm{~B}$, respectively. Upon increasing the concentration of RNA, a decrease of the peak current was observed. The strongest signal was generated by RNA1 (without mismatches), while the weakest signal was observed in case of RNA5 used as a negative reference.

A linear dynamic range for RNA1 was established from $3.0 \times 10^{3}$ to $3.0 \times 10^{5}$ RNA copies $/ \mu \mathrm{L}$. Limits of detection (LOD) were calculated according to the equation:

$L O D=\frac{3.3 \sigma}{s}$ 

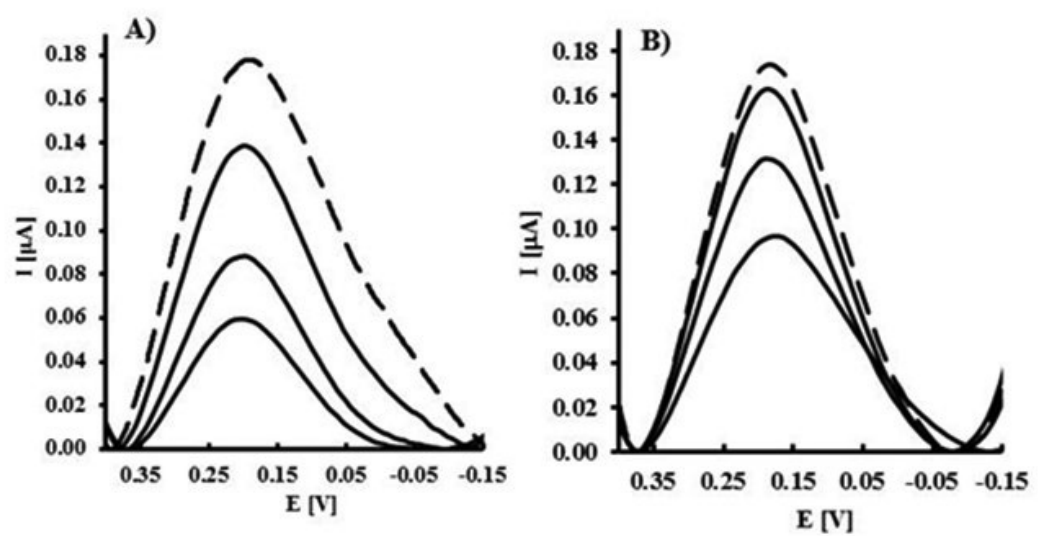

Figure 1. Typical OSW voltammograms obtained for electrodes modified with AuE/AET/ Fe(III)(Epoxy-Phen) ${ }_{3} / \mathrm{NH}_{2}$-ssDNA upon hybridization processes with RNA targets.

The dashed curve was registered before hybridization (pure buffer) and the next curves upon hybridization with (A) RNA1 and (B) RNA5. Measuring conditions: PBS pH 7.4 ( $n=5 / 6)$, RNA concentrations [number of copies/ $\mu \mathrm{L}$ ] - see Table 2.
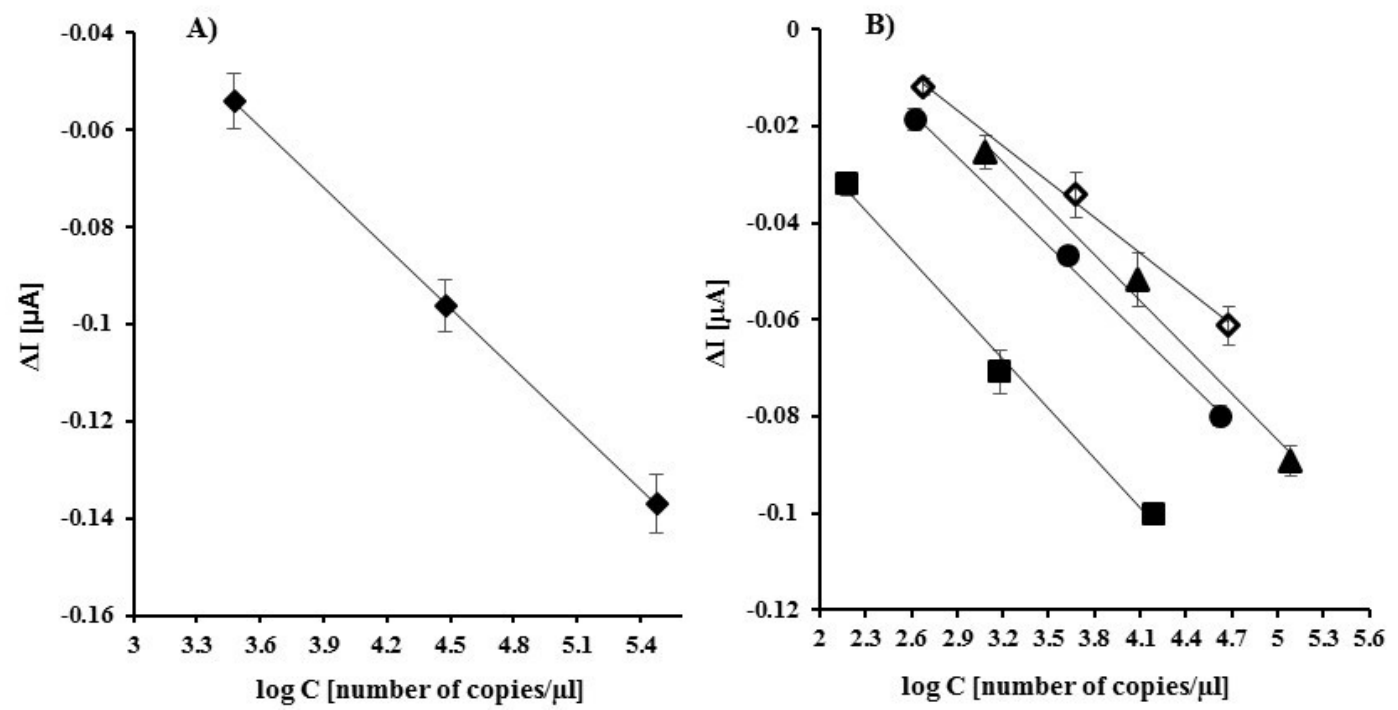

Figure 2. The relationship of $\Delta \mathrm{l}=\mathrm{I}-\mathrm{I},[\mathrm{\mu A}]$ versus $\log \mathrm{C}$ of:

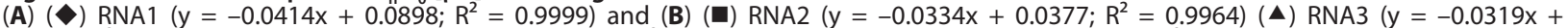
$\left.0.0749 ; R^{2}=0.9898\right)(\bullet)$ RNA4 $\left(y=-0.0306 x+0.0623 ; R^{2}=0.998\right)(\diamond)$ RNA5 $\left(y=-0.0247 x+0.055 ; R^{2}=0.9966\right)$. Measuring conditions: PBS pH 7.4; RNA concentrations [number of copies/ $\mu \mathrm{L}$ ] - see Table $2 ;(n=5 / 6), I_{n}$ is the value of the peak current measured in the presence of the RNA target and $I_{0}$ is the value of the peak current in pure PBS (before applying the analyte).

where $\sigma$ is the standard deviation of the response and $\mathrm{S}$ is the slope of the calibration curve (Swartz \& Krull, 2012). A remarkable detection limit of 3 copies $/ \mu \mathrm{L}(5$ aM) was obtained for RNA1.

The genosensor also showed good selectivity (Fig. 2). The signals generated by the highest concentration of RNA1 sample caused a $-0.137 \pm 0.006[\mu \mathrm{A}]$ decrease in the peak current. With the increase in number of mismatches in the RNA sequence, the signals became weaker. In case of RNA2, containing 2 mismatches, a decrease of $-0.100 \pm 0.004[\mu \mathrm{A}]$ was observed. RNA3 and RNA4 (sequences with 3 or 4 mismatches, respectively) generated a decrease in the peak current of about $-0.089 \pm 0.003[\mu \mathrm{A}]$ and $-0.080 \pm 0.002[\mu \mathrm{A}]$, respectively. RNA5, a non-complementary sequence, generated the weakest response with a decrease in the peak current of $-0.061 \pm 0.004[\mu \mathrm{A}]$.

The presented genosensor is able to distinguish in viral samples the complementary RNA fragments having 2,3 or 4 mismatches within the 20 -mer region hybridizing with the $\mathrm{NH}_{2}$-ssDNA probe.
The presented genosensor is superior to the other ones already published (Table 3).

To our knowledge, there are yet no reports on detecting and distinguishing mismatches present in complementary RNA sequences extracted from the influenza viruses using electrochemical genosensors.

The majority of reported electrochemical genosensors refer to the determination of DNA point mutations in buffer solutions or real samples (Joda et al., 2015; Sun et al., 2015; Yang et al., 2016; Rasheed et al., 2017).

Publications addressing RNA sensing in biological samples are limited to miRNA (containing about $22 \mathrm{nu}-$ cleotides) and we found no reports on longer RNA sequences sensing (Ren et al., 2013; Bartosik et al., 2014; Zhang et al., 2015; Azimzadeh et al., 2016). The main advantage of the proposed sensor is its suitability for direct determination of particular RNA sequences presence in biological material without any reverse transcription and amplification, which are a necessity when DNA is analyzed.

The designed biosensor exhibited good analytical performance towards RNA samples analysis and could be 
Table 3. Comparison of the presented and already published genosensors.

\begin{tabular}{|c|c|c|c|c|c|}
\hline $\begin{array}{l}\text { Electrode } \\
\text { modification }\end{array}$ & $\begin{array}{l}\text { Measuring } \\
\text { technique }\end{array}$ & Target & $\begin{array}{l}\text { Detection limit } \\
{[\mathrm{M}]}\end{array}$ & Medium & References \\
\hline \multirow{2}{*}{$\begin{array}{l}\text { AuE/AET/ Epoxy-Phen/ } \\
\text { FeCl } / \text { / Epoxy-Phen/ } \\
\mathrm{NH}_{2} \text {-sSDNA }\end{array}$} & \multirow{2}{*}{ OsWV } & ca. 280 mer RNA & $8.7 \times 10^{-13}$ & \multirow{2}{*}{ buffer } & \multirow{2}{*}{$\begin{array}{l}\text { Malecka et al., } \\
2015\end{array}$} \\
\hline & & 20-mer ssDNA & $7.3 \times 10^{-11}$ & & \\
\hline AuChip/SH-ssDNA/HRP & FPA & 112-mer ssDNA & - & clinical sample & Joda et al., 2015 \\
\hline \multirow[b]{2}{*}{ CILE/GR/NiO/ssDNA } & \multirow[b]{2}{*}{ DPV (MB) } & 24-mer ssDNA & $3.12 \times 10^{-14}$ & buffer & \multirow[b]{2}{*}{ Sun et al., 2015} \\
\hline & & $\begin{array}{l}\text { PCR products from } \\
\text { salmonella enteritidis } \\
\text { gene }\end{array}$ & - & biological sample & \\
\hline \multirow[b]{2}{*}{ AuE/SH-ssDNA/MCH/T/I/H1/H2 } & \multirow[b]{2}{*}{ DPV (RuHex) } & \multirow[b]{2}{*}{$\begin{array}{l}\text { 46-mer ssDNA } \\
\text { BRCA1 gene }\end{array}$} & $1 \times 10^{-18}$ & buffer & \multirow[b]{2}{*}{ Yang et al., 2016} \\
\hline & & & (n) & $\begin{array}{l}10 \mathrm{pM} \text { of DNA target } \\
\text { in a buffer:human } \\
\text { serum }(1: 1)\end{array}$ & \\
\hline GCE/g-CN/ssDNA & ChA (AuNPC) & $\begin{array}{l}\text { 19-mer ssDNA } \\
\text { BRCA1 gene }\end{array}$ & $10^{-17}$ & buffer & $\begin{array}{l}\text { Rasheed et al., } \\
2017\end{array}$ \\
\hline \multirow{2}{*}{ GCE/GO/AuN/SH-ssDNA/MCH } & \multirow{2}{*}{$\mathrm{DPV}(\mathrm{OB})$} & \multirow{2}{*}{ miRNA } & $0.6 \times 10^{-15}$ & buffer & \multirow{2}{*}{$\begin{array}{l}\text { Azimzadeh et al., } \\
2016\end{array}$} \\
\hline & & & - & diluted in plasma & \\
\hline \multirow[b]{2}{*}{ AuE/SH-ssDNA+TGA/DSN } & \multirow{2}{*}{$\begin{array}{l}\text { EIS } \\
\text { (Ferri/ferro) }\end{array}$} & \multirow[b]{2}{*}{ miRNA } & $1 \times 10^{-15}$ & buffer & \multirow[b]{2}{*}{ Ren et al., 2013} \\
\hline & & & - & $\begin{array}{l}2.2 \pm 0.53 \text { copies } / \mu \mathrm{g} \\
\text { in serum }\end{array}$ & \\
\hline $\mathrm{HMDE} / \mathrm{MBs} / \mathrm{BCP}$ & DPV & miRNA- Os(VI)bipy & - & $\begin{array}{l}\text { buffer/diluted in total } \\
\text { RNA sample }\end{array}$ & $\begin{array}{l}\text { Bartosik et al., } \\
2014\end{array}$ \\
\hline \multirow[b]{2}{*}{$\begin{array}{l}\text { AuE/C-ssDNA/MCH/H1+H2/ } \\
\text { ST-AP/ }\end{array}$} & \multirow[b]{2}{*}{ DPV (a-NP) } & \multirow[b]{2}{*}{ miRNA } & $0.6 \times 10^{-12}$ & buffer & \multirow[b]{2}{*}{ Zhang et al., 2015} \\
\hline & & & - & $\begin{array}{l}\text { diluted in total RNA } \\
\text { sample }\end{array}$ & \\
\hline $\begin{array}{l}\text { AuE/AET/ Epoxy-Phen/ } \\
\mathrm{FeCl}_{3} / \text { Epoxy-Phen/ } \\
\mathrm{NH}_{2} \text {-sSDNA }\end{array}$ & OSWV & RNA & $\begin{array}{l}5 \times 10^{-18} \\
(3 \text { copies } / \mu \mathrm{L})\end{array}$ & biological sample & Present study \\
\hline
\end{tabular}

Abbreviations: AuE, gold electrode; ssDNA, single stranded DNA; dsDNA, double stranded DNA; MCH, 6-mercaptohexan-1-ol; DPV, Differential Pulse Voltammetry; GCE, glassy carbon electrode; EIS, Electrochemical Impedance Spectroscopy; MB, Methylene Blue; Epoxy-Phen, 5,6-epoxy-5,6dihydro-[1.10]-phenanthroline; HRP, horseradish peroxidase; FPA, Fast Pulse Amperometry; CILE, carbon ionic liquid electrode; GR, graphene; NiO, nickel oxide; $\mathrm{H} 1$ and $\mathrm{H} 2$, hairpin probes; I, Initiator is a 48-base sequence that contains 24 bases at its $5^{\prime}$-end complementary to the unhybridized target sequence; TGA, thioglycolic acid; DSN, duplex-specific nuclease; g-CN, graphitic carbon nitride $g$ - $\mathrm{C}_{3} \mathrm{~N}_{4}$; ChA, Chronoamperometry; AuNPC, gold nanoparticles cluster; HMDE, hanging mercury drop electrode; MBs, magnetic beads; $\mathrm{BCP}$, biotinylated capture probe; $\mathrm{C}$-ssDNA, capture DNA probe; ST-AP, streptavidin-alkaline phosphatase; a-NP, a-naphthyl phosphate; GO, graphene oxide; AuN, gold nanorod; OB, oracet blue.

an alternative tool for detection of RNA in early diagnosis and biomedical research.

\section{CONCLUSIONS}

We applied an electrochemical genosensor based on AuE/AET/ $\mathrm{Fe}(\mathrm{III})$ (Epoxy-Phen) ${ }_{3} / \mathrm{NH}_{2}$-ssDNA redox-active layer for the direct detection of complementary RNA sequences in biological samples derived from influenza viruses. The DNA biosensor proved to be successful in the distinction of sequences containing the mismatches (2, 3 and 4$)$ in the 20-nt target region of the $\mathrm{NH}_{2}$-ssDNA probe. This particular trait of our genosensor may be useful in distinguishing between different, but closely related virus strains. The presented device is extremely sensitive, with the detection limit of 3 copies $/ \mu \mathrm{L}$ (5 aM). The major advantage of the presented sensor is its suitability for the direct determination of the target RNA present in biological samples, without the need of its amplifica- tion. Taken together, the presented sensor has a high potential to be added to the toolkit currently used for the virus detection in various samples, or even to replace some of the methods used. The most reliable results in identification of the virus would be achieved with the use of the combination of two or three probes complementary to different viral regions, which would also enable independent monitoring of the signal

\section{Acknowledgements}

The authors are very grateful to Prof. Zenon Minta and Prof. Krzysztof Smietanka from the Department of Poultry Disease of the National Veterinary Research Institute in Puławy, Poland for providing RNA samples and collaboration.

\section{Conflict of Interest}

The authors declare no conflict of interest. 


\section{REFERENCES}

Abi A, Mohammadpour Z, Zuo X, Safavi A (2018) Nucleic acid-based electrochemical nanobiosensors. Biosens Bioelectron 102: 479-489. https://doi.org/10.1016/j.bios.2017.11.019

Azimzadeh M, Rahaie M, Nasirizadeh N, Ashtari K, Naderi-Manesh $\mathrm{H}$ (2016) An electrochemical nanobiosensor for plasma miRNA-155, based on graphene oxide and gold nanorod, for early detection of breast cancer. Biosens Bioelectron 77: 99-106. https://doi. org/10.1016/j.bios.2015.09.020

Bahadır EB, Sezgintürk MK (2015) Applications of commercial biosensors in clinical, food, environmental and biothreat/biowarfare analyses. Anal Biochem 478: 107-120. https://doi.org/10.1016/j. ab.2015.03.011

Bartosik M, Hrstka R, Palecek E, Vojtesek B (2014) Magnetic beadbased hybridization assay for electrochemical detection of microRNA. Anal Chim Acta 813: 35-40. https://doi.org/10.1016/j. aca.2014.01.023

Fischer NO, Tarasow TM, Tok JBH (2007) Aptasensors for biosecurity applications. Curr Opin Chem Biol 11: 316-328. https://doi. org/10.1016/j.cbpa.2007.05.017

Grabowska I, Malecka K, Stachyra A, Góra-Sochacka A, Sirko A, Zagórski-Ostoja, W, Radecka H, Radecki J (2013) Single electrode genosensor for simultaneous determination of sequences encoding hemagglutinin and neuraminidase of avian influenza virus type H5N1. Anal Chem 85: 10167-10173. https://doi.org/10.1021/ ac401547h

Grabowska I, Singleton DG, Stachyra A, Góra-Sochacka A, Sirko A, Zagórski-Ostoja, W, Radecka H, Stulz E, Radecki J (2014a) A highly sensitive electrochemical genosensor based on Co-porphyrin-labelled DNA. Chem Commun 50: 4196-4199. https://doi. org/10.1039/c4cc00172a

Grabowska I, Stachyra A, Góra-Sochacka A, Sirko A, Olejniczak AB, Leśnikowski Z, Radecki J, Radecka H (2014b) DNA probe modified with 3-iron bis(dicarbollide) for electrochemical determination of DNA sequence of avian influenza virus H5N1. Biosens Bioelectron 51: 170-176. https://doi.org/10.1016/j.bios.2013.07.026

Joda H, Beni V, Katakis I, O'Sullivan CK (2015) DNA biosensor based on hybridization refractory mutation system approach for single mismatch detection. Anal Biochem 474: 66-68. https://doi. org/10.1016/j.ab.2014.11.021

Kaur B, Malecka K, Cristaldi DA, Chay CS, Mames I, Radecka H, Radecki J, Stulz E (2018) Approaching single DNA molecule detection with an ultrasensitive electrochemical genosensor based on gold nanoparticles and cobalt-porphyrin DNA conjugates. Chem Commun 54: 11108-11111. https://doi.org/10.1039/c8cc05362f

Kurzatkowska K, Sirko A, Zagórski-Ostoja W, Dehaen W, Radecka H, Radecki J (2015) Electrochemical label-free and reagentless genosensor based on an ion barrier switch-off system for dna sequencespecific detection of the Avian Influenza Virus. Anal Chem 87: 9702-9709. https://doi.org/10.1021/acs.analchem.5b01988

Li Z, Fu Y, Liao M, Li Y (2017) Biosensing methods for the detection of highly pathogenic avian influenza H5N1 and H7N9 viruses. Anal Methods 9: 5238-5248. https://doi.org/10.1039/c7av01585b.

Malecka K, Grabowska I, Radecki J, A. Stachyra, A. Góra-Sochacka, A. Sirko, H. Radecka (2012) Voltammetric detection of specific DNA sequence of Avian Influenza Virus H5N1 using DNA probe deposited onto gold electrode. Electroanalysis 24: 39-46. https://doi. org/10.1002/elan.201100566

Malecka K, Grabowska I, Radecki J, Stachyra A, Góra-Sochacka A, Sirko A, Radecka H (2013) Electrochemical detection of Avian Influenza Virus genotype using amino-ssDNA probe modified gold electrodes. Electroanalysis 25: 1871-1878. https://doi.org/10.1002/ elan.201300113

Malecka K, Stachyra A, Góra-Sochacka A, Sirko A, Zagórski-Ostoja W, Dehaen W, Radecka H, Radecki J (2015) New redox-active layer create via epoxy-amine reaction-the base of genosensor for the detection of specific DNA and RNA sequences of avian influenza virus H5N1. Biosens Bioelectron 65: 427-434. https://doi.org/10.1016/j. bios.2014.10.069

Malecka K, Stachyra A, Góra-Sochacka A, Sirko A, Zagórski-Ostoja W, Radecka H, Radecki J (2016) Electrochemical genosensor based on disc and screen printed gold electrodes for detection of specific DNA and RNA sequences derived from Avian Influenza Virus H5N1. Sens Actuators B 224: 290-297. https://doi.org/10.1016/j. snb.2015.10.044

Manzanares-Palenzuela CL, Martín-Clemente JP, Lobo-Castañón MJ, López-Ruiz B (2017) Electrochemical detection of magnetically- entrapped DNA sequences from complex samples by multiplexed enzymatic labelling: Application to a transgenic food/feed quantitative survey. Talanta 164: 261-267. https://doi.org/10.1016/j.talanta.2016.11.040

Mehrotra P (2016) Biosensors and their applications - A review. J Oral Biol Craniofacial Res 6: 153-159. https://doi.org/10.1016/j.jobcr.2015.12.002

Moulick A, Richtera L, Milosavljevic V, Cernei N, Haddad Y, Zitka O, Kopel P, Heger Z, Adam V (2017) Advanced nanotechnologies in avian influenza: Current status and future trends - A review. Anal Chim Acta 983: 42-53. https://doi.org/10.1016/j.aca.2017.06.045

Mukama O, Sinumvayo JP, Shamoon M, Shoaib M, Mushimiyimana H, Safdar W, Bemena L, Rwibasira P, Mugisha S, Wan Z (2017) An update on aptamer-based multiplex system approaches for the detection of common foodborne pathogens. Food Anal Methods 10: 2549-2565. https://doi.org/10.1007/s12161-017-0814-5

Ozkan-Ariksoysal D, Kayran YU, Yilmaz FF, Ciucu AA, David IG, David V, Hosgor-Limoncu M, Ozsoz M (2017) DNA-wrapped multi-walled carbon nanotube modified electrochemical biosensor for the detection of Escherichia coli from real samples. Talanta 166: 27-35. https://doi.org/10.1016/j.talanta.2017.01.005

Paniel N, Baudart J, Havat A, Barthelmebs L (2013) Aptasensor and genosensor methods for detection of microbes in real world samples. Methods 64: 229-240. https://doi.org/10.1016/j.ymeth.2013.07.001

Radecka H, Radecki J, (2015) Development of electrochemical sensors for DNA analysis. In DNA in Supramolecular Chemistry and Nanotechnology. Stulz E, Clever GH eds, pp 139-157. First Edition, John Wiley \& Sons.

Radecka H, Radecki J, (2016) Electrochemical sensors for detections of influenza viruses: fundamentals and applications. In Steps Forwards in Diagnosing and Controlling Influenza. Baddour MM eds, pp 47-59. In'TechOpen. https://dx.doi.org/10.5772/64423

Rasheed PA, Radhakrishnan T, Nambiar SR, Thomas RT, Sandhyarani N (2017) Graphitic carbon nitride as immobilization platform for ssDNA in a genosensor. Sens Actuators B 250: 162-168. https://doi. org/10.1016/j.snb.2017.04.141

Ren Y, Deng H, Shen W, Gao Z (2013) A highly sensitive and selective electrochemical biosensor for direct detection of microRNAs in serum. Anal Chem 85: 4784-4789. https://doi.org/10.1021/ ac400583e

Shojaei TR, Tabatabaei M, Shawky S, Salleh MAM, Bald D (2015) A review on emerging diagnostic assay for viral detection: the case of avian influenza virus. Mol Biol Rep 42: 187-199. https://doi. org/10.1007/s11033-014-3758-5

Sun W, Wang X, Lu Y, Gong S, Qi X, Lei B, Sun Z, Li G (2015) Electrochemical deoxyribonucleic acid biosensor based on electrodeposited graphene and nickel oxide nanoparticle modified electrode for the detection of salmonella enteritidis gene sequence. $\mathrm{Ma}$ ter Sci Eng C 49: 34-39. https://doi.org/10.1016/j.msec.2014.12.071

Swartz EM and Krull IS (2012) Handbook of Analytical Validation, $3^{\text {rd }}$ ed. CRC Press, Taylor \& Francis Group: Boca Raton, FL, p.70

Śmietanka K, Minta Z (2014) Avian Influenza in Poland. Acta Biochim Pol 61: 453-457.

Śmietanka K, Niemczuk K, Świętoń E, Niemczuk P (2017) Highly pathogenic avian influenza $\mathrm{H} 5$ subtype in Europe and Poland in years 2016/2017 - current situation, control measures, risk assessment. Życie Weterynaryjne 92: 481-485.

Tosar JP, Brañas G, Laíz J (2010) Electrochemical DNA hybridization sensors applied to real and complex biological samples. Biosens Bioelectron 26: 1205-1217. https://doi.org/10.1016/j.bios.2010.08.053

Vidic J, Manzano M, Chang C-M, Jaffrezic-Renault N (2017) Advanced biosensors for detection of pathogens related to livestock and poultry. Vet Res 48: 11. https://doi.org/10.1186/s13567-017-0418-5

Yang H, Gao Y, Wang S, Qin Y, Xu L, Jin D, Yang F, Zhang GJ (2016) In situ hybridization chain reaction mediated ultrasensitive enzyme-free and conjugation-free electrochemcial genosensor for BRCA-1 gene in complex matrices. Biosens Bioelectron 80: 450-455. https://doi.org/10.1016/j.bios.2016.02.011

Zhang BH, Wang RH, Wang YX, Li Y (2016) LabVIEW-based impedance biosensing system for detection of avian influenza virus. Int J Agric Biol Eng 9: 116-122. https://doi.org/10.3965/j. ijabe.20160904.1704

Zhang Y, Yan Y, Chen W, Cheng W, Li S, Ding X, Li D, Wang H, Ju H, Ding S (2015) A simple electrochemical biosensor for highly sensitive and specifisc detection of microRNA based on mismatched catalytic hairpin assembly. Biosens Bioelectron 68: 343-349. https://doi.org/10.1016/j.bios.2015.01.026 